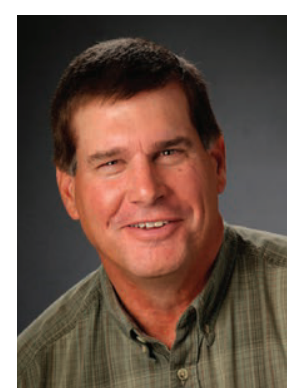

By Jeff Mosley

\title{
Browsing the Literature
}

This section reviews new publications available about the art and science of rangeland management. Personal copies of these publications can be obtained by contacting the respective publishers or senior authors (addresses shown in parentheses). Suggestions are welcomed and encouraged for items to include in future issues of Browsing the Literature. Contact Jeff Mosley, jmosley@montana.edu.

\section{Animal Ecology}

Avian abundance and reproductive success in the Intermountain West: local-scale response to the Conservation Reserve Program. W.M. Vander Haegen, M.A. Schroeder, W.Y. Yang, and S.M. Knapp. 2015. Wildlife Society Bulletin 39:276-291. (Washington Dept of Fish and Wildlife, 600 Capitol Way North, Olympia, WA 98501, USA). Nest survival of grassland and shrubland birds was equal to or greater in Conservation Reserve Program (CRP) grasslands than in sagebrush steppe and was similar for CRP planted with native versus introduced grasses.

Indirect effects of red imported fire ants on Attwater's prairie-chicken brood survival. M.E. Morrow, R.E. Chester, S.E. Lehnen, B.M. Drees, and J.E. Toepfer. 2015. Journal of Wildlife Management 79:898-906. (Attwater Prairie Chicken National Wildlife Refuge, PO Box 519, Eagle Lake, TX 77434, USA). "Our results clearly document that invertebrate abundance affects Attwater's prairie-chicken brood survival and that fire ants may indirectly contribute to low brood survival by suppressing invertebrate abundance."

Predator identity influences the effect of habitat management on nest predation. T.P. Lyons, J.R. Miller, D.M. Debinski, and D.M. Engle. 2015. Ecological Applications 25:1596-1605. (Illinois Natural History Survey, 1816 S. Oak St, Champaign, IL 61820, USA). Grasshopper sparrow predation by mammals and snakes was more likely at nests with large amounts of litter and grass cover.

Spatial distributions and resource selection by mule deer in an arid environment: responses to provision of water. C.J. McKee, K.M. Stewart, J.S. Sedinger, A.P. Bush, N.W. Darby, D.L. Hughson, and V.C. Bleich. 2015. Journal of Arid Environments 122:76-84. (K. Stewart, Dept of Natural Resources and Environmental Science, Univ of Nevada, Reno, NV 89557, USA). Mule deer in southeastern California selected areas close to water during all seasons of the year.

\section{Grazing Management}

Dormant season grazing may decrease wildfire probability by increasing fuel moisture and reducing fuel amount and continuity. K.W. Davies, C.S. Boyd, J.D. Bates, and A. Hulet. 2015. International Journal of Wildland Fire 24:849-856. (USDA-Agricultural Research Service, 67826-A Highway 206, Burns, OR 97720, USA). In sagebrush steppe of 
southeastern Oregon, winter cattle grazing reduced herbaceous fuels the following summer without increasing exotic annual grass yield and without reducing basal cover or yield of perennial bunchgrasses.

Increased preparation for drought among livestock producers reliant on rain-fed forage. M.P. McClaran, G.J. Butler, H. Wei, and G.D. Ruyle. 2015. Natural Hazards 79:151-170. (School of Natural Resources and the Environment, Univ of Arizona, Tucson, AZ 85712, USA). Following 10 very dry years, $68 \%$ of ranchers in southeastern Arizona reported at least some increased preparation for drought. Developing written contingency plans, reserving pastures for use during drought, and implementing rotational grazing systems to better enable forage plants to withstand drought were the most common drought preparedness strategies.

\section{Hydrology/Riparian}

Activity of insectivorous bats associated with cattle ponds at La Michilia Biosphere Reserve, Durango, Mexico: implications for conservation. C. Lopez-Gonzalez, E.P. Gomez-Ruiz, A. Lozano, and R. Lopez-Wilchis. 2015. Acta Chiropterologica 17:117-129. (Unidad Durango, Instituto Politecnico Nacional, Sigma 119 Fraccionamiento 20 Noviembre II, Durango, Durango 34220, Mexico). Stockwater ponds in northern Mexico provide important foraging resources and drinking water for bats in an area with the world's largest population of insectivorous bats.

Characteristics within and around stopover wetlands used by migratory shorebirds: is the neighborhood important? G. Albanese, and C.A. Davis. 2015. Condor 117:328-340. (C. Davis, Dept of Natural Resource Ecology and Management, Oklahoma State Univ, Stillwater, OK 74078 , USA). A survey of more than 14,000 wetlands in north-central Oklahoma revealed that shorebird abundance and diversity were favored by livestock grazing and disfavored by trees and shrubs and urban-suburban development.

Introduced reed canary grass attracts and supports a common native amphibian. K.A. Holzer, and S.P. Lawler. 2015. Journal of Wildlife Management 79:1081-1090. (Dept of Entomology and Nematology, Univ of California-Davis, Davis, CA 95616, USA). In western Oregon, males of the common native Pacific chorus frog preferred to call from reed canary grass plants and females preferred to lay their eggs on this introduced invasive grass where tadpoles had seven times greater survival. Two other native amphibians also benefited from reed canary grass.

Patch-burn grazing effects on the ecological integrity of tallgrass prairie streams. K.E. Jackson, M.R. Whiles, W.K. Dodds, J.D. Reeve, J.M. Vandermyde, and H.M. Rantala. 2015. Journal of Environmental Quality 44:1148-1159. (PO Box 102406, Columbia, SC 29224, USA). Riparian exclusion fencing was needed to prevent patch-burn cattle grazing from degrading water quality of tallgrass prairie headwater streams in Missouri.

Persistence at distributional edges: Columbia spotted frog habitat in the arid Great Basin, USA. R.S. Arkle, and D.S. Pilliod. 2015. Ecology and Evolution 5:3704-3724. (US Geological Survey, 970 Lusk St, Boise, ID 83706, USA). Intensive livestock grazing and predation by native and non-native trout inhibited Columbia spotted frogs in the Great Basin of Nevada, Utah, Oregon, and southern Idaho.

Sensitivity of secretive marsh birds to vegetation condition in natural and restored wetlands in Wisconsin. W.J. Glisson, R.S. Brady, A.T. Paulios, S.K. Jacobi, and D.J. Larkin. 2015. Journal of Wildlife Management 79:1101-1116. (Dept of Fish and Wildlife Sciences, Univ of Idaho, Moscow, ID 83844). The marsh birds American bitten and Virginia rail were disfavored where reed canary grass was abundant, while sora occupancy was favored by cattails.

Tamarix transpiration along a semiarid river has negligible impact on water resources. A.K. McDonald, B.P. Wilcox, G.W. Moore, C.R. Hart, Z.P. Sheng, and M.K. Owens. 2015. Water Resources Research 51:5117-5127. (Texas A\&M AgriLife Extension, PO Box 1298, Fort Stockton, TX 79735, USA). Transpiration by saltcedar was low compared with stream discharge, which likely explains why streamflow did not increase after saltcedar control along the Pecos River in southwestern Texas.

\section{Plant Ecology}

A limited role for apparent competition via granivory in the persistence of a grassland invader. T.M. Radtke, and S.D. Wilson. 2015. Journal of Vegetation Science 26:995-1004. (S. Wilson, Dept of Biology, Univ of Regina, Regina, SK S4S 0A2, Canada). Granivory of native plant seeds by birds and small animals in crested wheatgrass stands does not explain crested wheatgrass persistence.

Short-term harvesting of biomass from conservation grasslands maintains plant diversity. J.M. Jungers, C.C. Sheaffer, J. Fargione, and C. Lehman. 2015. GCB Bioenergy 7:1050-1061. (Dept of Agronomy and Plant Genetics, Univ of Minnesota, Saint Paul, MN 55108, USA). In Minnesota grasslands enrolled in USDA Natural Resources Conservation Service conservation programs, biofuel harvest did not affect plant biodiversity or relative abundance of the main plant functional groups.

The ghosts of trees past: savanna trees create enduring legacies in plant species composition. K.A. Stahlheber, K.L. Crispin, C. Anton, and C.M. D'Antonio. 2015. Ecology 96:2510-2522. (W.K. Kellogg Biological Station, Michigan State Univ, Hickory Corners, MI 59060, USA). In oak savannas of California, low-diversity understory plant 
communities persisted up to 43 years following the death of a tree.

Top-down control of rare species abundances by native ungulates in a grassland restoration. B.J. Wilsey, and L.M. Martin. 2015. Restoration Ecology 23:465-472. (Dept of Ecology, Evolution and Organismal Biology, Iowa State Univ, Ames, IA 50011, USA). Plant species diversity in tallgrass prairie of Iowa was greater with moderate bison grazing than without grazing.

\section{Rehabilitation/Restoration}

Emergence and early survival of early versus late seral species in Great Basin restoration in two different soil types. S.M. Uselman, K.A. Snyder, E.A. Leger, and S.E. Duke. 2015. Applied Vegetation Science 18:624-636. (Dept of Natural Resources and Environmental Science, Univ of Nevada, Reno, NV 89557, USA). On sites infested with either cheatgrass or medusahead, seeding early seral native species was more successful than using later seral species found in traditional seed mixes.

Fire effects on invasive and native warm-season grass species in a North American grassland at a time of extreme drought. S. Havill, S. Schwinning, and K.G. Lyons. 2015. Applied Vegetation Science 18:637-649. (S. Schwinning, Dept of Biology, Texas State Univ, San Marcos, TX 78666, USA). In central Texas, prescribed fire applied during the summer of a drought year may create a competitive advantage for the native little bluestem versus the invasive, introduced yellow bluestem.

Imazapic activity in a semiarid climate in downy brome (Bromus tectorum)-infested rangeland and CRP sites. K.A. Ehlert, R.E. Engel, and J.M. Mangold. 2015. Weed Technology 29:472-479. (Dept of Land Resources and Environmental Sciences, Montana State Univ, Bozeman, MT 59717, USA). "These results indicate that fall imazapic applications in semiarid climates persist into the spring, thus providing control of both fall-emerging downy brome seedlings and seeds that overwinter and emerge the following spring."

The role of ecotypic variation and the environment on biomass and nitrogen in a dominant prairie grass. M.L. Mendola, S.G. Bauer, L.C. Johnson, and B.R. Maricle. 2015. Ecology 96:2433-2445. (S. Bauer, Dept of Plant Biology, Southern Illinois Univ, Carbondale, IL 62901, USA). Big bluestem yield on highly mesic sites was greater when seeded with locally adapted ecotypes than when seeded with ecotypes native to much drier regions.

\section{Socioeconomics}

Conflicts between cattlemen and the Florida panther: insights and policy recommendations from interviews with Florida cattlemen. E.F. Pienaar, M.M. Kreye, and C. Jacobs. 2015. Human Ecology 43:577-588. (Dept of Wildlife Ecology and Conservation, Univ of Florida, Gainesville, FL 32611, USA). Current and proposed government incentive programs are unlikely to achieve recovery of the federally endangered Florida panther. Authors suggest providing payments contingent on keeping lands as unimproved pasture (i.e., rangeland) without mandating particular land management practices.

\section{Soils}

Long-term grassland intensification impacts on particle-size soil carbon fractions: evidence from carbon-13 abundance. J.B. Adewopo, M.L. Silveira, S.T. Xu, S. Gerber, L.E. Sollenberger, and T. Martin. 2015. Soil Science Society of America Journal 79:1198-1205. (M. Silveira, Range Cattle Research and Education Center, Univ of Florida, 3401 Experiment Station Rd, Ona, FL 33865, USA). Twenty-two years after conversion from native rangeland, soil carbon was greater in silvopasture and tame pasture than in unconverted native rangeland of south-central Florida.

Nitrous oxide production and consumption by denitrification in a grassland: effects of grazing and hydrology. J. $\mathrm{Hu}$, K.S. Inglett, M.W. Clark, P.W. Inglett, and K.R. Reddy. 2015. Science of the Total Environment 532:702-710. (K. Reddy, Soil and Water Science Dept, Univ of Florida, Gainesville, FL 32611, USA). Cattle grazing in south-central Florida did not affect denitrification rates in wetland or upland soils.

Jeff Mosley is Professor of Range Science and Extension Range Management Specialist, Department of Animal and Range Sciences, Montana State University, Bozeman, MT 59717.

Rangelands (37)6:247-249

doi 10.1016/j.rala.2015.10.004

(C) 2015 The Society for Range Management 